\title{
Anestesia em Paciente com Distrofia Muscular de Duchenne. Relato de Caso *
}

\section{Anesthesia in Duchenne's Muscular Dystrophy Patient. Case Report}

Deoclécio Tonelli, TSA ${ }^{1}$; Iglair Pinho ${ }^{2}$; Paula de Camargo Neves Sacco, TSA ${ }^{3}$; Eduardo Piccinini Vianna ${ }^{4}$; José Correia de Vasconcellos, TSA ${ }^{5}$; Raquel Vasconcelos de Souza ${ }^{6}$; Sidney Umakoshi ${ }^{6}$

\section{RESUMO}

Tonelli D, Pinho I, Sacco PCN, Vianna EP, Vasconcellos JC, Souza RV, Umakoshi S - Anestesia em Paciente com Distrofia Muscular de Duchenne. Relato de Caso

JUSTIFICATIVA E OBJETIVOS: A distrofia muscular de Duchenne é uma afecção recessiva ligada ao cromossomo $X$, geralmente diagnosticada na infância, acentuando-se progressivamente até agravar a função respiratória. O objetivo deste relato é apresentar um caso de um paciente com distrofia muscular de Duchenne diagnosticada há 2 anos, submetido à postectomia, sob anestesia geral com cetamina $S$.

RELATO DO CASO: Paciente com 9 anos de idade com Distrofia Muscular de Duchenne diagnosticada há 2 anos, submetido à anestesia geral com levo-cetamina $\left(1,5 \mathrm{mg} \cdot \mathrm{kg}^{-1}\right)$, por via venosa, sob ventilação espontânea assistida manualmente por sistema de Baraka (Mapleson A) e bloqueio peniano com bupivacaína a 0,5\% (25 mg). Foram usados monitores de pressão arterial não invasiva, oximetria de pulso, cardioscopia e temperatura esofagiana. No decorrer da cirurgia, o caso evoluiu sem intercorrências, sendo que no período pós-operatório o paciente apresentou alguns episódios de vômitos sem outras alterações significativas. Permaneceu internado por 24 horas, tendo alta hospitalar assintomático.

CONCLUSÕES: A avaliação pré-anestésica cuidadosa, o uso de monitorização adequada e medicações que não predisponham o aparecimento de complicações tornam seguro o procedimento em pacientes portadores de Distrofia Muscular de Duchenne e seu pós-operatório.

Unitermos: ANESTESIA, Pediátrica; DOENÇAS: distrofia muscular de Duchenne

\section{SUMMARY}

Tonelli D, Pinho I, Sacco PCN, Vianna EP, Vasconcellos JC, Souza RV, Umakoshi S - Anesthesia in Duchenne's Muscular Dystrophy Patient. Case Report

BACKGROUND AND OBJECTIVES: Duchenne's Muscular Dystrophy is an $X$-linked recessive disorder, generally diagnosed in childhood, which progressively worsens to degenerate respiratory function. This report aimed at presenting the case of a patient with Duchenne's Muscular Dystrophy diagnosed 2 years before, submited to postectomy under general anesthesia with ketamine $S$.

CASE REPORT: Male patient, 9 years old, with Duchenne's Muscular Dystrophy diagnosed 2 years before, submitted to general anesthesia with intravenous levo-ketamine (1.5 $\mathrm{mg} \cdot \mathrm{kg}^{-1}$ ), under spontaneous ventilation manually assisted by Mapleson A Baraka system and penile block with $25 \mathrm{mg}$ of $0.5 \%$ bupivacaine. Monitoring consisted of non invasive blood pressure, pulse oximetry, cardioscopy and esophageal temperature. There were no incidents during surgery, and after surgery patient had a few vomiting episodes, without other significant complications. Patient remained in hospital for 24 hours and was discharged asymptomatic.

CONCLUSIONS: Very careful pre-anesthetic evaluation, adequate monitoring and drugs not predisposing to complications make surgery and postoperative period safe for Duchenne's Muscular Dystrophy patients.

Key Words: ANESTHESIA, Pediatric; DISEASES: Duchenne's muscular dystrophy

na infância, acentuando-se progressivamente até agravar a função respiratória ${ }^{1}$.

Estudos pré-operatórios de miopáticos mostraram que $83 \%$ dos pacientes têm alterações do ECG, 26\% insuficiência cardíaca, $31 \%$ alterações à radiografia de tórax e $73 \%$ restrição pulmonar grave ${ }^{1}$.

As complicações esperadas na anestesia destes pacientes são hipertermia maligna, rabdomiólise e parada cardiocirculatória, disritmias e insuficiência cardíaca, além de limitações respiratórias e cardíacas ${ }^{2-9}$. Febre, sintomas de rabdomiólise (hipercalemia, mioglobinúria) e espasmo de masseter também foram descritos ${ }^{4,10-13}$, além de um relato de anafilaxia devido à exposição ao látex ${ }^{15}$.

A succinilcolina foi envolvida na gênese da maioria dos acidentes fatais relatados pela literatura ${ }^{4,5,7,12}$, apesar de permanecer como droga muito utilizada na prática anestésica pediátrica $^{14}$.

\footnotetext{
do ABC, São Bernardo do Campo, SP

1. Responsável pelo CET Integrado da FMABC; Chefe do Serviço de Dor Anestesiologia do Hospital São Caetano

2. Professor Titular da Disciplina de Anestesiologia da FMABC

4. Assistente do Hospital de Ensino Padre Anchieta

6. EX-ME $E_{2}$ do CET Integrado da FMABC

Endereço para correspondência (Correspondence to) Dr. Deoclécio Tonelli

Rua Domingos Augusto Setti 73 Ap 22 - Chácara Klabin, V. Mariana 04116-070 São Paulo - SP

Apresentado (Submitted) em 11 de julho de 2001

Aceito (Accepted) para publicação 28 de outubro de 2002

(C) Sociedade Brasileira de Anestesiologia, 2003
}

Revista Brasileira de Anestesiologia Vol. 53, № 3, Maio - Junho, 2003 
Diante destas características, os pacientes portadores de distrofia de Duchenne necessitam de cuidados especiais em todo o período perianestésico.

O objetivo deste relato é mostrar um caso de uma criança de 9 anos de idade com distrofia muscular de Duchenne há 2 anos, submetida à postectomia sob anestesia geral com cetamina $\mathrm{S}$ e bloqueio peniano.

\section{RELATO DO CASO}

Paciente com 9 anos de idade, do sexo masculino, branco, com diagnóstico de distrofia muscular de Duchenne há 2 anos e insuficiência respiratória restritiva leve, em fisioterapia respiratória. Sem relato de internações anteriores, distúrbios cardíacos e uso de medicações.

Foi encaminhado ao ambulatório de Anestesiologia para avaliação pré-anestésica, a fim de realizar postectomia.

O paciente chegou ao ambulatório deambulando com auxílio de muletas, dificuldade em manter posição supina sem apoio. Apresentava escoliose grave e atrofia muscular difusa. $O$ restante do exame físico era normal. Os exames complementares pré-operatórios eram normais, exceto a prova de função pulmonar, que mostrou insuficiência respiratória restritiva leve.

No dia da cirurgia não foi administrada medicação pré-anestésica.

Foi realizada venopunção com cateter venoso periférico $22 \mathrm{G}$ com perfeita cooperação do paciente e monitorização com oxímetro de pulso, monitor cardíaco, pressão arterial não invasiva e temperatura esofagiana. Foram administrados $200 \mathrm{ml}$ de solução de Ringer com lactato durante a cirurgia, para reposição das perdas do jejum e da cirurgia, considerada de pequeno porte.

Optou-se por anestesia geral com cetamina levógira (1,5 $\left.\mathrm{mg} \cdot \mathrm{kg}^{-1}\right)$, sob ventilação espontânea, após lavagem do sistema respiratório do aparelho de anestesia por 3 horas e bloqueio peniano com bupivacaína a 0,5\%.

O procedimento cirúrgico durou 30 minutos, sem intercorrências.

No pós-operatório imediato, o paciente apresentou vários episódios de vômitos, sendo convenientemente tratados com metoclopramida $\left(0,15 \mathrm{mg} \cdot \mathrm{kg}^{-1}\right)$ e foi realizado controle rígido da freqüência respiratória e cardíaca, da temperatura e da pressão arterial não invasiva durante todo o período da internação, recebendo alta hospitalar no dia seguinte à cirurgia.

\section{DISCUSSÃO}

De acordo com os dados da literatura, a distrofia muscular de Duchenne é um distúrbio recessivo ligado ao cromossomoX, também chamada de Distrofia Muscular Pseudohipertrófica, tendo incidência de 30 por 10.000 nascidos vivos do sexo masculino. As manifestações clínicas estão presentes desde o nascimento, mas tornam-se evidentes entre os três e cinco anos de idade. Caracterizam-se por perda progressiva da força muscular, com predileção pelos músculos proximais dos membros e pelos músculos flexores do pescoço. Aos 12 anos de idade, a maioria dos pacientes está confinada à cadeira de rodas. Dos 16 aos 18 anos os pacientes estão predispostos às graves infecções pulmonares, por vezes fatais. Outra causa de óbito é a aspiração alimentar. É comum apresentarem comprometimento intelectual e terem degeneração miocárdica, que desencadeia insuficiência cardíaca direita insidiosa. O diagnóstico é feito por biópsia muscular, que mostra deficiência de distrofia no tecido muscular ou por análise de mutação em leucócitos de sangue periférico.

O tratamento da distrofia muscular de Duchenne é feito com prednisona.

São pacientes que necessitam de cuidados especiais no ato anestésico e precisam de uma avaliação pré-anestésica criteriosa, com exame físico e anamnese detalhados e dirigidos à doença, pois poderão apresentar uma série de complicações relacionadas ao procedimento anestésico ${ }^{22,23}$.

A medicação pré-anestésica não é recomendada, por poder induzir à depressão respiratória ${ }^{1}$ ou atuar no relaxamento muscular, como é o caso dos benzodiazepínicos ${ }^{16}$.

$\mathrm{Na}$ anestesia estão contra-indicados os anestésicos halogenados pelo potencial risco de hipertermia maligna ${ }^{1,3,5-7,9,17} \mathrm{e}$ a succinilcolina, por estar relacionada a vários relatos de rabdomiólise peri-anestésica e parada cardiocirculatória, em que muitas vezes a hipercalemia foi a causa da complicação 4-8,10-13,18-20

A cetamina, além de não estar relacionada às complicações mais freqüentes, é uma droga sugerida para a anestesia deste grupo de pacientes ${ }^{1,21}$. Outras drogas venosas, como o propofol e o tiopental sódico, também podem ser utilizadas, tomando-se cuidado com a cardiodepressão e sensibilidade individual à depressão respiratória ${ }^{1}$. Devido à curta duração da cirurgia e a não utilização de bloqueadores neuromusculares, optou-se pela ventilação espontânea sem intubação orotraqueal.

O período pós-operatório deve ser monitorizado, pois as complicações cardiovasculares também ocorrem nesta fase, assim como a elevação da temperatura caracterizando hipertermia maligna ${ }^{9}$. Também são freqüentes os vômitos devido à hipotonia dos músculos abdominais, favorecendo a dilatação gástrica ${ }^{1}$, fato que também foi observado no paciente em questão.

Concluímos deste relato que a avaliação pré-anestésica cuidadosa e o uso de medicações que não predisponham ao aparecimento de complicações tornam seguros o procedimento e o pós-operatório de pacientes com distrofia muscular de Duchenne. 


\section{Anesthesia in Duchenne's Muscular Dys- trophy Patient. Case Report}

Deoclécio Tonelli, TSA, M.D., Iglair Pinho, M.D., Paula de Camargo Neves Sacco, TSA, M.D., Eduardo Piccinini Vianna, M.D., José Correia de Vasconcellos, TSA, M.D., Raquel Vasconcelos de Souza, M.D., Sidney Umakoshi, M.D.

\section{INTRODUCTION}

Duchenne's Muscular Dystrophy is an X-linked recessive disorder, generally diagnosed during childhood, which progressively worsens to degenerate respiratory function ${ }^{1}$. Preoperative evaluation of affected patients have shown that $83 \%$ have ECG abnormalities, $26 \%$ heart failure, $31 \%$ chest $X$-ray changes and $73 \%$ severe pulmonary restriction ${ }^{1}$.

Expected anesthetic complications are malignant hyperthermia, rhadbomyolysis and cardiac arrest, arrhythmias and heart failure, in addition to respiratory and cardiac limitations ${ }^{2-9}$. Fever, rhabdomyolysis symptoms (hyperkalemia, mioglobinuria) and masseter spasm have also been reported ${ }^{4,10-13}$, in addition to an anaphylaxis report due to latex exposure ${ }^{15}$.

Succinylcholine was involved in the genesis of most fatal accidents reported in the literature ${ }^{4,5,7,12}$ although remaining a widely used drug for pediatric anesthesia ${ }^{14}$. Due to such characteristics, Duchenne's dystrophy patients need special care throughout the anesthetic procedure.

This report aimed at describing a case of a 9-year old child with Duchenne's Muscular Dystrophy diagnosed 2 years before, submitted to postectomy under general anesthesia with ketamine $\mathrm{S}$, and penile block.

\section{CASE REPORT}

Male, Caucasian patient, 9 years old, with Duchenne's Muscular Dystrophy diagnosed 2 years before and mild restrictive respiratory failure under respiratory physical therapy, without previous history of hospital admissions, cardiac disease or use of drugs.

Patient was referred to the Anesthesiology department for preanesthetic evaluation to be submitted to postectomy. Patient arrived walking with the use of crutches and with difficulty in maintaining the supine position without support. Patient presented severe scoliosis and diffuse muscular atrophy. Remaining physical evaluation was normal. Preoperative tests were normal except for pulmonary function test which showed mild restrictive respiratory failure.

Patient was not premedicated.

Venous puncture was performed with a peripheral $22 \mathrm{G}$ catheter with perfect cooperation of the patient who was monitored with pulse oximetry, heart monitor, non-invasive blood pressure and esophageal temperature. Lactated Ringer's (200 $\mathrm{ml}$ ) was administered during surgery to replace fast and surgery losses, considered minor.
The choice was general anesthesia with levogyrous ketamine $\left(1.5 \mathrm{mg} \cdot \mathrm{kg}^{-1}\right)$ under spontaneous ventilation after washing the respiratory system of the anesthesia machine for 3 hours, and penile block with $0.5 \%$ bupivacaine.

Surgery lasted 30 minutes without intercurrences.

Patient had several vomiting episodes in the immediate postoperative period, which were conveniently treated with metoclopramide $\left(0.15 \mathrm{mg} . \mathrm{kg}^{-1}\right)$. Respiratory and heart rate, temperature and blood pressure were closely monitored during the whole admission period and patient was discharged the day after surgery.

\section{DISCUSSION}

According to data in the literature, Duchenne's Muscular Dystrophy is an X-linked recessive disorder, also called Pseudhypertrophic Muscular Dystrophy, with an incidence of 30 out of 10 thousand male live borns. Clinical manifestations are present since birth, but become apparent between 3 and 5 years of age. The disease is characterized by progressive muscle strength loss, especially limb proximal and neck flexor muscles. At 12 years of age, most patients are confined to wheelchairs. From 16 to 18 years of age patients are predisposed to severe, sometimes fatal, pulmonary infections. Another cause of death is food aspiration. Patients have often intellectual impairment and myocardial degeneration triggering insidious right heart failure. Diagnosis is obtained by muscle biopsy showing muscle tissue dystrophy or by mutation analysis in peripheral blood leucocytes.

Duchenne's muscular dystrophy is treated with prednisone.

These are patients needing special care during anesthesia and a judicious preanesthetic evaluation with physical exams, detailed and disease-related history because they may present several anesthesia-related complications ${ }^{22,23}$.

Preanesthetic medication is not recommended because it may induce respiratory depression ${ }^{1}$ or act on muscle relaxation, as it is the case with benzodiazepines ${ }^{16}$.

Halogenate anesthetics are counterindicated in anesthesia due to the potential risk for malignant hyperthermia ${ }^{1,3,5-7,9,17}$, as well as succinylcholine for being related to several peri-anesthetic rhabdomyolysis and cardiac arrest where many times hyperkalemia was the reason for the complication 4-8, 10-13,18-20

Ketamine, in addition to being unrelated to most common complications, is a drug suggested for anesthesia in this group of patients ${ }^{1,21}$. Other intravenous drugs, such as propofol and sodium thiopental, may also be used, however being careful with cardiocirculatory depression and individual sensitivity to respiratory depression ${ }^{1}$. Due to the short surgery duration and the non-use of neuromuscular blockers, we decided for spontaneous ventilation without tracheal intubation.

The postoperative period should be monitored because cardiovascular complications are also present during this stage, as well as temperature increase characterizing malignant hyperthermia ${ }^{9}$. Vomiting is also frequent due to abdominal 
muscles hypotonia favoring gastric dilatation ${ }^{1}$, fact which has also been observed in our patient.

We concluded from this report that careful preanesthetic evaluation and drugs not predisposing to complications make both surgery and the postoperative period safe for Duchenne's Muscular Dystrophy patients.

\section{REFERÊNCIAS - REFERENCES}

01. Gaudiche O, Meistelman C - Anesthésie du myopathe. Paris France, Encycl Méd Chir, Anesthésie-Réanimation, 1990;36657-D-10:6.

02. Wollinsky $\mathrm{KH}$, Weiss $\mathrm{C}$, Gelowicz $\mathrm{M}$ et al - Preoperative risk assessment of children with Duchenne muscular dystrophy and intra and postoperative course. Med Klin, 1996;91(Suppl 2): 34-37.

03. Oka S, Igarashi Y, Takagi A et tal - Malignant hyperpyrexia and Duchenne muscular dystrophy. A case report. Can Anaesth Soc J, 1982;29:627-629.

04. Breucking E, Reimnitz P, Schara U et al - Anesthetic complications. The incidence of severe anesthetic complications in patients and families with progressive muscular dystrophy of the Duchenne and Becker types. Anaesthesist, 2000;49:187-195.

05. Sethna NF, Sockoff MA - Cardiac arrest following inhalation induction of anaesthesia in a child which Duchenne's muscular dystrophy. Can Anaesth Soc J, 1986;33:799-802.

06. Chalkiadis GA, Branch KG - Cardiac arrest after isoflurane in a patient with Duchenne muscular dystrophy. Anaesthesia, 1990;45:22-25.

07. Smith CL, Bush GH - Anaesthesia and progressive muscular dystrophy. Br J Anaesth, 1985;57:1113:1118.

08. Stelzner J, Kretz FJ, Rieger A et al - Anesthetic-induced heart arrest. A case report of 2 infants with previously unrecognized muscular dystrophy. Anaesthesist, 1993:42:44-46.

09. Taguchi A, Takada K, Horiuchi F et al - Anesthetic management of a patient with Duchenne's muscular dystrophy undergoing radical repair for tetralogy of Fallot. Masui, 1997;46:12, 1594-1598

10. Mckishnie JD, Muir JM, Girvan DP - Anaesthesia induced rhabdomyolysis: a case report. Can Anaesth Soc J, 1983;30:3PT1:295-298.

11. Larach MG, Rosemberg H, Gronert GA et al - Hyperkalemia cardiac arrest during anesthesia in infants and children with occult myopathies. Clin Pediatr, 1997;36:9-16.

12. Sullivan M, Thompson WK, Hill GD - Succinylcholine-induced cardiac arrest in children with undiagnosed myopathy :see comments. Can J Anaesth, 1994;41:497-501.

13. Obata R, Yasumi Y, Suzuki A et al - Rhabdomyolysis in association which Duchenne's muscular dystrophy :see comments. Can J Anaesth, 1999;46:564-566.

14. Robinson AL, Jerwood DC, Stokes MA - Routine suxamethonium in children. A regional survey of current usage: see comments. Anaesthesie, 1996;51:874-878.

15. Dormans JP, Templeton JJ, Edmonds C et al - Intraoperative anaphylaxis due to exposure to latex (natural rubber) in children. J Bone Joint Surg Am, 1994;76:1688-1691.
16. Inibitory effects of diazepam and midazolam in $\mathrm{Ca}$ and $\mathrm{K}$ channels in tracheal muscle of dog. Anesthesiology, 1999;90: 330-333.

17. Schneider V, Eyrich K, Stelzner J - Muscular dystrophy as a risk factor in anesthesia. Versicherungsmedizin, 1992;44:133-137.

18. Tang TT, Oechler HW, Siker D et al - Anesthesia-induced rhabdomyolysis in infants with unsuspected Duchenne dystrophy. Acta Paediatr, 1992;81:716-719.

19. Benton NC, Wolgat RA - Sudden cardiac arrest during adenotonsillectomy in a patient with subclinical Duchenne's muscular dystrophy. Ear Nose Throat J, 1993;72;130-131.

20. Arnould JF, Bigot A, Steenbeke L et al - Heart arrest during general anesthesia in a child with unrecognized Duchenne's dystrophy. Ann Fr Anesth Reanim, 1986,5:612-614.

21. Fiacchino F, Bricchi M, Gemma M et al - Pre and postoperative evaluation of plasma creatine kinase in 142 children subjected to "uncomplicated" anesthesia in muscle biopsy. Minerva Anestesiol, 1989;55:11-19

22. Aminoff MJ - Nervous System, em: Tierney LM, McPhee SJ, Papadakis MA - Current Medical Diagnosis \& Treatment. $38^{\text {th }}$ Ed, Stamford, Appleton \& Lange, 1999;987-990.

23. Morgan GE, Mikhail MS - Anesthesia for Patients with Neuromuscular Disease, em: Morgan GE, Mikhail MS - Clinical Anesthesiology. $2^{\text {nd }}$ Ed, Stamford, Appleton \& Lange, 1996;650-655.

\section{RESUMEN}

Tonelli D, Pinho I, Sacco PCN, Vianna EP, Vasconcellos JC, Souza RV, Umakoshi S - Anestesia en Paciente con Distrofia Muscular de Duchenne. Relato de Caso

JUSTIFICATIVA Y OBJETIVOS: La distrofia muscular de Duchenne es una afección recesiva ligada al cromosoma $X$, generalmente diagnosticada en la infancia, acentuándose progresivamente hasta agravar la función respiratoria. El objetivo de este relato es presentar un caso de un paciente con distrofia muscular de Duchenne diagnosticada hace 2 años, sometido a la postectomia, sobre anestesia general con cetamina $S$.

RELATO DE CASO: Paciente con 9 años de edad con Distrofia Muscular de Duchenne diagnosticada hace 2 años, sometido a la anestesia general con levo-cetamina $\left(1,5 \mathrm{mg} \cdot \mathrm{kg}^{-1}\right)$, por vía venosa, sobre ventilación espontanea auxiliada manual por sistema de Baraka (Mapleson A) y bloqueo peniano con bupivacaína a 0,5\% (25 mg). Fueron usados monitores de presión arterial no invasiva, oximetria de pulso, cardioscopia y temperatura esofagiana. En el recurrir de la cirugía, el caso evoluyó sin interocurrencias siendo que en el período pós-operatorio el paciente presentó algunos episodios de vómitos sin otras alteraciones significativas. Permaneció internado por 24 horas, teniendo alta hospitalar asintomático. CONCLUSIONES: La evaluación pré-anestésica cuidadosa, el uso de monitorización adecuada y medicaciones que no predispongan al aparecimiento de complicaciones tornan seguro el procedimiento y el pós-operatorio en pacientes portadores de Distrofia Muscular de Duchenne. 